Part of Journal of Research of the National Bureau of Standards, Volume 32, April 1944

\title{
THERMAL EXPANSION OF HIGH-SILICON CAST IRON
}

\author{
By Peter Hidnert and George Dickson
}

\section{ABSTRACT}

This paper gives data on the linear thermal expansion of high-silicon cast iron containing approximately 14 percent of silicon, with 3 percent of molybdenum and without appreciable molybdenum, at various temperatures between $20^{\circ}$ and $700^{\circ}$ C. Differences between the coefficients of expansion of these high-silicon cast irons were found to be slight. Both high-silicon cast irons were found to have slightly higher coefficients of expansion than electrolytic iron for temperature ranges between $20^{\circ}$ and $300^{\circ} \mathrm{C}$, and appreciably higher coefficients for higher temperature ranges. No indication of growth similar to that of ordinary cast iron was observed on heating the high-silicon cast iron to $700^{\circ} \mathrm{C}$.

\section{CONTENTS}

II. Material investigated

II. Material investigated _.

III. Apparatus _._.

IV. Results and discussion _...

V. References

\section{INTRODUCTION}

In 1938 , discordant values $\left(0.7 \times 10^{-5}\right.$ and $0.36 \times 10^{-5}$ per degree Fahrenheit between $32^{\circ}$ and $212^{\circ} \mathrm{F}$ ) were reported by manufacturers [1] for the coefficient of linear thermal expansion of high-silicon cast iron containing 14.5 percent of silicon. The lower value was also reported [1] ${ }^{1}$ for a 14.5 -percent silicon cast iron containing 3 percent of molybdenum. The work reported in the present paper was undertaken in order to determine definitely the coefficients of expansion of high-silicon cast iron with 3 percent of molybdenum and without appreciable molybdenum, for various temperature ranges between $20^{\circ}$ and $700^{\circ} \mathrm{C}$.

Some of the uses of high-silicon cast iron are indicated in an anonymous paper [2] and in a book by Greiner, Marsh, and Stoughton [3]. For example, high-silicon cast iron is used where resistance to hot concentrated sulfuric acid, copper sulfate solutions, or tin tetrachloride is required.

High-silicon cast iron containing usually 14 to 16 percent of silicon and 1 percent or less of carbon is known [1,3] by a variety of trade names, such as Antaciron, Durichlor, Duriron, Elianite, Fersilite, Ironac, Métillure, Tantiron, and Thermsilid.

\footnotetext{
${ }^{1}$ Numbers in brackets indicate the literature references at the end of this paper.
} 


\section{MATERIAL INVESTIGATED}

Two annealed high-silicon cast irons obtained from the Duriron Co., Inc., Dayton, Ohio, were used in this investigation. Table 1 gives the chemical composition of the samples. The diameter of sample 1678 was $11 \mathrm{~mm}$, and the cross section of sample 1679 was 8 by $8 \mathrm{~mm}$. Each sample was ground to a length of $300 \mathrm{~mm}$ with the ends cylindrical (radius $150 \mathrm{~mm}$ ). The samples could not be machined on account of their brittleness.

\section{APPARATUS}

The precision micrometric thermal-expansion apparatus described by Souder and Hidnert [4] was used for the determinations of linear thermal expansion. Figure 4 of their publication indicates the method used in mounting the samples in the furnace. A platinum-osmium (about $6 \frac{1}{2}$ percent of osmium) observation wire 0.002 inch in diameter was in contact with each end of the sample.

\section{RESULTS AND DISCUSSION}

Figures 1 and 2 show the observations on the linear thermal expansion of the two high-silicon cast irons at various temperatures between

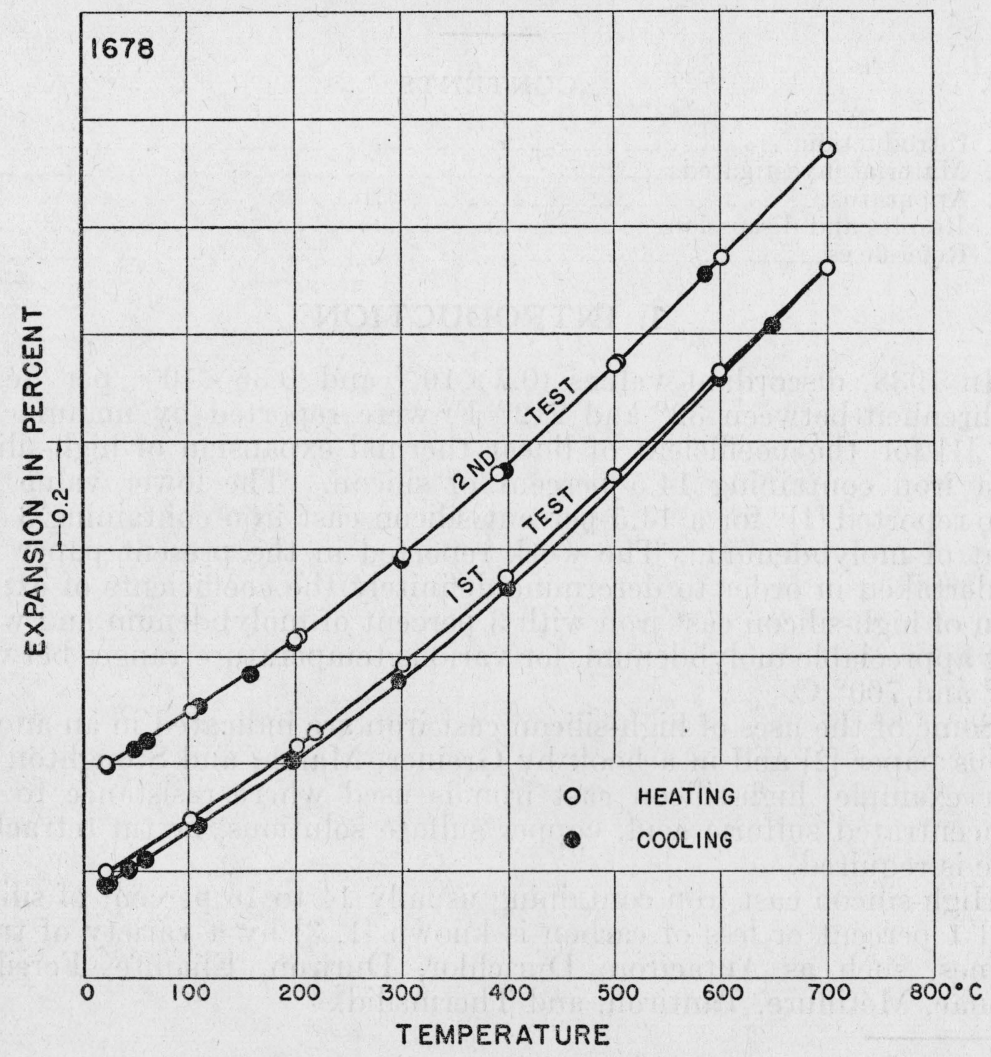

FiguRe 1.-Linear thermal expansion of high-silicon cast iron. $\mathrm{Si}, 14.7$; Mn, 0.75; C, 0.41; S, 0.015; P, 0.023; Mo, 0.05 percent. 
$20^{\circ}$ and $700^{\circ} \mathrm{C}$. In the first test of each cast iron, there was a divergence between the expansion and the contraction curve, but in the second test these curves nearly coincided.

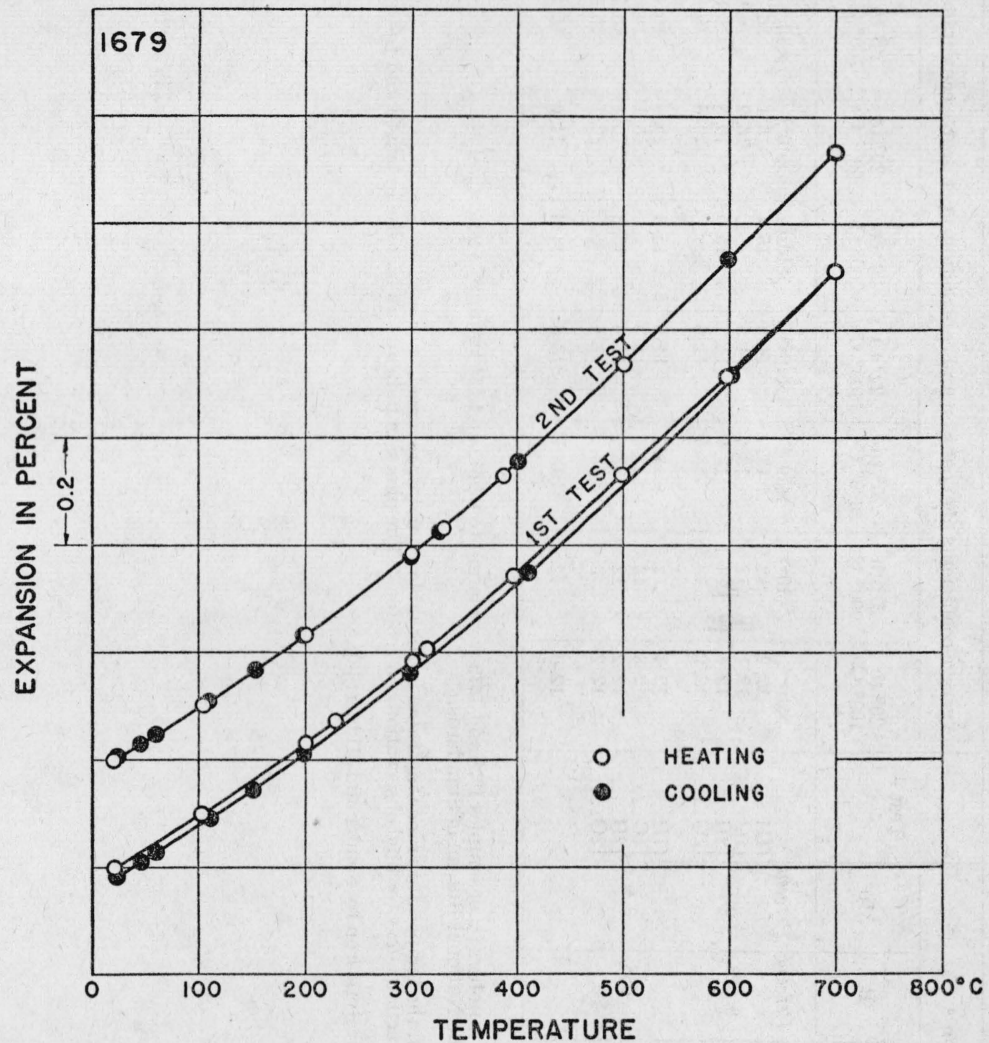

FIGURE 2.-Linear thermal expansion of high-silicon cast iron containing molybdenun Si, $14.0 ;$ Mo, $3.0 ; \mathrm{Mn}, 0.62 ; \mathrm{C}, 0.91 ; \mathrm{S}, 0.011 ; \mathrm{P}, 0.088$ percent.

Table 1 gives the coefficients of expansion and the coefficients of contraction that were obtained from the curves in figures 1 and 2 . The maximum difference in all coefficients derived for any one temperature range was $0.4 \times 10^{-6}$ for sample 1678 and $0.3 \times 10^{-6}$ for sample 1679. The differences in the composition of the high-silicon cast iron containing 3 percent of molybdenum and of a similar cast iron containing 0.05 percent of molybdenum appear to have slight effect on the linear thermal expansion. The last column of table 1 indicates the permanent changes in length which occurred as a result of the heating and cooling in each test. 
TABLE 1.-Coefficients of linear expansion and contraction of annealed a high-silicon cast irons

\begin{tabular}{|c|c|c|c|c|c|c|c|c|c|c|c|c|c|c|c|c|}
\hline \multirow[b]{2}{*}{ Sample b } & \multirow[b]{2}{*}{ Commercial name } & \multicolumn{6}{|c|}{ Chemical composition $\bullet$} & \multirow[b]{2}{*}{ Test d } & \multicolumn{7}{|c|}{ A verage coefficients of expansion and contraction ${ }^{\circ}$ per degree centigrade } & \multirow{2}{*}{$\begin{array}{c}\text { Change } \\
\text { in length } \\
\text { after } \\
\text { heating } \\
\text { and } \\
\text { cooling } \mathbf{c}\end{array}$} \\
\hline & & $\mathrm{Si}$ & $\mathrm{Mn}$ & $\mathrm{C}$ & $\mathrm{S}$ & $\mathrm{P}$ & Mo & & $\begin{array}{l}20^{\circ} \text { to } \\
100^{\circ} \mathrm{C}\end{array}$ & $\begin{array}{l}20^{\circ} \text { to } \\
200^{\circ} \mathrm{C}\end{array}$ & $\begin{array}{r}20^{\circ} \text { to } \\
300^{\circ} \mathrm{C}\end{array}$ & $\begin{array}{l}20^{\circ} \text { to } \\
400^{\circ} \mathrm{C}\end{array}$ & $\begin{array}{l}20^{\circ} \text { to } \\
500^{\circ} \mathrm{C}\end{array}$ & $\begin{array}{l}20^{\circ} \text { to } \\
600^{\circ} \mathrm{C}\end{array}$ & $\begin{array}{l}20^{\circ} \text { to } \\
700^{\circ} \mathrm{C}\end{array}$ & \\
\hline $1678 \ldots$ & Duriron..... & $\begin{array}{r}\text { Percent } \\
14.7\end{array}$ & $\begin{array}{c}\text { Percent } \\
0.75\end{array}$ & $\begin{array}{r}\text { Percent } \\
0.41\end{array}$ & $\begin{array}{r}\text { Percent } \\
0.015\end{array}$ & $\begin{array}{c}\text { Percent } \\
0.023\end{array}$ & $\begin{array}{r}\text { Percent } \\
0.05\end{array}$ & $\left\{\begin{array}{l}1 \mathrm{H} \\
1 \mathrm{C} \\
2 \mathrm{H} \\
2 \mathrm{C}\end{array}\right.$ & $\begin{array}{r}\times 10-6 \\
12.2 \\
12.1 \\
12.4 \\
12.2\end{array}$ & $\begin{array}{r}\times 10-6 \\
12.9 \\
12.9 \\
13.1 \\
12.9\end{array}$ & $\begin{array}{r}\times 10^{-6} \\
13.7 \\
13.7 \\
13.9 \\
13.7\end{array}$ & $\begin{array}{r}\times 10^{-6} \\
14.6 \\
14.5 \\
14.7 \\
14.6\end{array}$ & $\begin{array}{r}\times 10^{-6} \\
15.4 \\
15.5\end{array}$ & $\begin{array}{r}\times 10-6 \\
16.1 \\
16.2 \\
16.3 \\
16.3\end{array}$ & $\begin{array}{r}\times 10^{-6} \\
16.5 \\
16.9 \\
16.8 \\
16.8\end{array}$ & $\left\{\begin{array}{l}\text { Percent } \\
-0.022 \\
-.002\end{array}\right.$ \\
\hline 1679. & Durichlor... & 14.0 & .62 & .91 & .011 & .088 & 3. 0 & $\left\{\begin{array}{l}1 \mathrm{H} \\
1 \mathrm{C} \\
2 \mathrm{H} \\
2 \mathrm{C}\end{array}\right.$ & $\begin{array}{l}12.4 \\
12.3 \\
12.2 \\
12.2\end{array}$ & $\begin{array}{l}12.9 \\
13.0 \\
12.9 \\
13.0\end{array}$ & $\begin{array}{l}13.7 \\
13.7 \\
13.7 \\
13.7\end{array}$ & $\begin{array}{l}14.5 \\
14.5 \\
14.6 \\
14.4\end{array}$ & $\begin{array}{l}15.3 \\
15.3\end{array}$ & $\begin{array}{l}15.9 \\
16.1 \\
16.1 \\
16.1\end{array}$ & \begin{tabular}{l|}
16.4 \\
16.6 \\
16.7 \\
16.6
\end{tabular} & $\begin{array}{l}-.018 \\
+.003\end{array}$ \\
\hline $507 \mathbf{g}_{-}$ & Electrolytic iron.- & & & & & & & & 12. 0 & 12.6 & 13. 3 & 13.8 & 14.3 & 14. 7 & 15.1 & \\
\hline
\end{tabular}

Heated to $1,700^{\circ} \mathrm{F}\left(927^{\circ} \mathrm{C}\right)$ and cooled slowly.

b Before the expansion tests, determinations of Knoop hardness numbers [5] of samples 1678 and 1679 were found to be 612 and $554 \mathrm{~kg} / \mathrm{mm}^{2}$, respectively.

- Determined by John P. Hewlett, Jr. and James I. Shultz, of the National Bureau of Standards.

d H represents heating and C cooling.

i Determined from the expansion curve on heating and the contraction curve (or final observation) on cooling. The plus sign indicates an increase in length and the minus sign a decrease in length.

g Added for comparison with high-silicon cast iron (data on electrolytic iron by Souder and Hidnert [6]). 
The average coefficient of expansion of the high-silicon cast iron (without appreciable molybdenum) for the range from $20^{\circ}$ to $100^{\circ} \mathrm{C}$ is in agreement with the higher of two values reported [1] in 1938. However, the average coefficient of expansion of the high-silicon cast iron (with 3 percent of molybdenum) for the temperature range from $20^{\circ}$ to $100^{\circ} \mathrm{C}$ is nearly twice the low value reported in the same publication.

The coefficients of expansion of the two high-silicon cast irons are greater than the coefficients of expansion of electrolytic iron ${ }^{2}$ reported by Souder and Hidnert [6]. For temperature ranges between $20^{\circ}$ and $300^{\circ} \mathrm{C}$, the coefficients of expansion of these cast irons are slightly greater than the coefficients of expansion of electrolytic iron, and for higher temperature ranges the coefficients of the former are appreciably greater than the coefficients of the latter.

The results shown in figures 1 and 2 revealed no indication of growth of the high-silicon cast irons on heating to $700^{\circ} \mathrm{C}$, similar to that observed in the case of ordinary cast iron [6].

\section{REFERENCES}

[1] Data sheets on materials of construction, Chem. Met. Eng. 45, 650 (1938).

[2] Where high-silicon irons serve chemical industry, Chem. Met. Eng. 36, 541 (1921).

[3] E. S. Greiner, J. S. Marsch, and B. Stoughton, The Alloys of Iron and Silicon (Published for the Engineering Foundation by the McGraw-Hill Book Co., Inc., New York and London, 1933).

[4] W. Souder and P. Hidnert, Measurements on the thermal expansion of fused silica, Sci. Pap. BS 21, 1 (1926) S524.

[5] F. Knoop, C. G. Peters, and W. B. Emerson, A sensitive pyramidal-diamond tool for indentation measurements, J. Research NBS 23, 39 (1939) RP1220.

[6] W. Souder and P. Hidnert, Thermal expansion of a few steels, Sci. Pap. BS 1\%, 611 (1922) S433.

Washington, December 27, 1943.

2 See last line of table 1. 